\title{
"Job change and self-control of waste pickers: evidence from a field experiment in the Philippines"
}

Hide-Fumi Yokoo iD https://orcid.org/0000-0001-7923-4587

AUTHORS

Maki lkuse

Aries Roda D. Romallosa

Masahide Horita

Hide-Fumi Yokoo, Maki Ikuse, Aries Roda D. Romallosa and Masahide Horita

ARTICLE INFO (2018). Job change and self-control of waste pickers: evidence from a field experiment in the Philippines. Environmental Economics, 9(2), 22-35. doi: 10.21511/ee.09(2).2018.02

DOI http://dx.doi.org/10.21511/ee.09(2).2018.02

RELEASED ON

Friday, 15 June 2018

RECEIVED ON

Wednesday, 02 May 2018

ACCEPTED ON

Wednesday, 13 June 2018

\section{(cc) EY-NG}

LICENSE

This work is licensed under a Creative Commons Attribution-NonCommercial 4.0 International License

JOURNAL "Environmental Economics"

ISSN PRINT 1998-6041

ISSN ONLINE 1998-605X

PUBLISHER LLC "Consulting Publishing Company "Business Perspectives"

FOUNDER

LLC "Consulting Publishing Company "Business Perspectives"

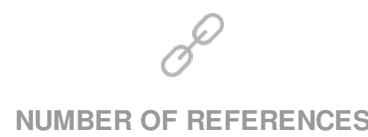

38
NUMBER OF FIGURES

1
NUMBER OF TABLES

5

(C) The author(s) 2022. This publication is an open access article. 


\title{
Hide-Fumi Yokoo (Japan), Maki Ikuse (Japan), Aries Roda D. Romallosa (the Philippines), Masahide Horita (Japan)
}

\section{Job change and self-control of waste pickers: evidence from a field experiment in the Philippines}

\begin{abstract}
Environmental policies may have a negative side effect on employment, often in a specific industry in the short run. Workers in regulated industries can be affected by losses in job-specific human capital. The informal sectors in developing countries are often associated with environmental pollution and thus targeted by such policies. Welfare loss due to this side effect can be problematic in developing countries, since they often lack safeguarding schemes, including unemployment insurance. Inducing workers in informal sectors to change their jobs can mitigate these negative side effects. This study examines efficient methods of inducing informal workers to change jobs. An alternative job is offered to informal workers at a dumpsite in the Philippines and whether changing the scheme of wage payment increases the acceptance of the offer is examined. The impacts of changing payment schemes are evaluated by using a randomized field experiment. The sampled 112 waste pickers each randomly receive one of four offers for an alternative job, and the number of those who accept the offer is observed to evaluate the impact of less frequent payment (i.e., once every three days instead of daily). Piece rates and fixed wages are also compared. Those offered less frequent payment are more likely to accept the job offer compared with those offered daily payment. This preferred payment scheme can mitigate the side effects of environmental policy and workers' self-control problem related to savings, while minimizing moral hazard.
\end{abstract}

Keywords: field experiment, job change, payment schemes, side effect of an environmental policy, waste management, waste pickers.

JEL Classification: J33, M52, O13, Q53.

Received on: $02^{\text {nd }}$ of May, 2018

Accepted on: $13^{\text {th }}$ of June, 2018

\section{Introduction}

Increasing environmental regulation may have a negative side effect on employment, often in a specific industry in the short run. Workers in regulated industries may be affected by job losses and/or losses in job-specific human capital. Job losses can be considered to be the costs of environmental policies if the affected workers suffer from costly job transitions such as decreased income and high adjustment costs for a new job (Walker, 2011). Further, welfare loss due to this side effect may be more problematic in developing countries, since they often lack safeguarding schemes, including unemployment insurance.

The informal sectors in developing countries are

(c) Hide-Fumi Yokoo, Maki Ikuse, Aries Roda D. Romallosa, Masahide Horita, 2018.

Hide-Fumi Yokoo, Ph.D., Researcher at the National Institute for Environmental Studies, Tsukuba, Japan.

Maki Ikuse, M.S., Economic Development Researcher at the Ministry of Foreign Affairs, Tokyo, Japan.

Aries Roda D. Romallosa, Ph.D., Full Professor at the Department of Agricultural Engineering and Environmental Management, Central Philippine University, Iloilo City, the Philippines.

Masahide Horita, Ph.D., Professor at the Department of International Studies, The University of Tokyo, Kashiwa, Japan.

This is an Open Access article, distributed under the terms of the Creative Commons Attribution-NonCommercial 4.0 Internationallicense, which permits re-use, distribution, and reproduction, provided the materials aren't used for commercial purposes and the original work is properly cited often associated with environmental pollution and thus targeted by such regulations (Blackman \& Bannister, 1998; Blackman et al., 2006). Inducing workers in informal sectors to change their jobs can mitigate the negative side effects of environmental regulation in many cases. Therefore, efficient methods to induce job changes by informal workers have gained policy prominence.

A common example of informal workers in many developing countries are waste pickers, namely individuals who collect recyclable waste at an open dumpsite (Hayami et al., 2006; Wilson et al., 2009) ${ }^{1}$. Open dumping is a widely used waste disposal practice in developing countries. This practice causes several environmental problems such as bad smells and dirty leachate. Moreover, once this practice has been employed, the land

\footnotetext{
${ }^{1}$ Birkbeck (1978) is the first study to describe the organization of waste pickers in Colombia, finding that they work independently and are effectively paid on a piece work basis. Subsequent studies have explored the business practices and livelihood of waste pickers in the United States and Mexico (Medina, 1998), India (Hayami et al., 2006; Gill, 2007), Pakistan (Asim et al., 2012), Indonesia (Sasaki \& Araki, 2013), the Philippines (Paul et al., 2012), Brazil (Gutberlet \& Baeder, 2008; Tirado-Soto \& Zamberlan, 2013), and Nigeria (Agunwamba, 2003; Nzeadibe, 2009). Parizeau (2015) surveys waste pickers who work on the streets of Buenos Aires, Argentina. Although most of the above research comprises qualitative studies based on small surveys, Moreno-Sanchez and Maldonado (2006) extend a theoretical model of household recycling to integrate the role of waste pickers and perform a numerical simulation.
} 
cannot be used for other purposes such as agriculture for a long time, which means a real economic loss. Thus, agencies operating waste management services (e.g., municipalities) may plan to close open dumpsites to decrease those costs. However, changing to a more environmentally friendly practice such as sanitary landfilling would inevitably harm waste pickers (Medina, 2000; Paul et al., 2012). To minimize the social cost of solid waste including the negative side effect of environmental management, it is therefore important to safeguard waste pickers by providing alternative job opportunities before the closure of open dumpsites and inducing them to change their jobs (Medina, 2000).

This study empirically examines some such methods of inducing informal workers to change their jobs. In this study, an alternative job is offered to waste pickers and whether changing the scheme of wage payment increases the acceptance of the offer is examined. A field experiment is conducted at a dumpsite in Iloilo City, the Philippines, where 112 waste pickers are offered an alternative job. Each individual randomly receives one of four types of offer letters and the number of those who accept their offer is observed.

The experiment has three objectives. Based on evidence of demand for commitment devices (Bryan et al., 2010), including the finding by Ashraf et al. (2006) that individuals who exhibit timeinconsistent preferences in a survey are more likely to take up a commitment savings product that restricts customers' access to their funds, the first objective of the experiment is to evaluate the extent to which less frequent payment (i.e., payment every three days) affects the acceptance of a job offer by informal workers.

The job offered in the experiment is the production of solid fuels, and an important feature of this production is the easy measurement of the output. According to the theory of optimal compensation (Lazear, 1995, 1998), if the measurement of the output is costless, then piece rate pay with a price equal to the marginal cost achieves an efficient level of effort by a worker and minimizes moral hazard, whereas fixed wages do not.

The second objective of the experiment is to compare the extent to which piece rate pay and fixed wages affect the acceptance of the offer. Several studies empirically examine the relationship between compensation systems and labor supply (Prendergast, 1999). For example, Shearer (2004) estimates the gain in the productivity of workers in a tree-planting firm in Canada when they are paid piece rates rather than fixed wages, finding that productivity is higher for workers who receive piece rate pay. While existing studies focus on the impact of changing the compensation system on labor supply conditional on job choice, however, the present study compares the effects of piece rates and fixed wages on occupational choice.

Finally, although piece rate pay can provide an incentive for workers to provide their maximum effort, an employer cannot raise its profit as long as the price of the output equals the marginal cost. For instance, Lazear (1998) provides a piece rate pay scheme with a fixed salary (i.e., a draw) to raise profit, while maintaining an incentive for workers. The third objective of the present experiment is thus to investigate whether piece rate pay with a draw, which is beneficial for an employer, induces the acceptance of the offer, as well as pure piece rate pay does.

The results show that changing payment frequency from daily to once every three days increases the probability that an individual accepts a new job offer, which is counterintuitive to the monotonicity assumption of the discount rate. Using piece rate pay paid once every three days, 27 percent of the recipients are induced to accept the offer. This acceptance rate is slightly higher than the fixed wage of around half of the average daily earnings in collecting waste, which is paid once every three days. There is no positive or negative effect for adding a draw, implying that it may be possible to raise profit without decreasing the acceptance rate.

The findings of this study make several contributions to the field of environmental and resource economics. First, this study extends the literature on environmental policies and unemployment as its side effect (Bovenberg \& van der Ploeg, 1994). Several empirical studies find evidence of such a side effect (Greenstone, 2002; Walker, 2011, 2013; Liu et al., 2017; Zaied et al., 2018); however, investigations of methods to mitigate the effect are surprisingly rare. This study therefore bridges the gap in the literature by proposing treatments to induce job changes at the time of the implementation of new environmental management practices.

Second, this study contributes to the literature on the environmental impacts of the informal sector (Hayami et al., 2006; Blackman et al., 2006; Biswas et al., 2012) and on environmental policies when there is an informal sector (Blackman, 2000; Chaudhuri \& Mukhopadhyay, 2006; Moreno- 
Sanchez \& Maldonado, 2006; Baksi \& Bose, 2016). This study is the first to use a randomized field experiment to study the behavioral responses of informal workers. While various theoretical studies analyze individuals' choices between formal and informal jobs (e.g., Fugazza \& Jacques, 2004; Albrecht et al., 2009), empirical studies are rare ${ }^{2}$. For empirical studies of the informal sector, the collection of micro data is challenging. For example, many waste pickers do not have mailing addresses or personal identification. Furthermore, the population of waste pickers working at a dumpsite is difficult to identify. Therefore, random sampling is difficult (Hayami et al., 2006). Owing to these difficulties, few econometric analyses have been carried out to investigate the association between informal sectors and environmental management. An exception is the seminal work by Blackman and Bannister (1998) who use primary data on 76 informal brick makers in Mexico to study the determinants of the adoption of clean fuel. While there are a few empirical studies of the behavior of informal workers, all rely on nonexperimental data. Of particular concern when using nonexperimental data is the possible endogeneity problem. One way in which this problem can be solved is to use data from a field experiment. Although the sample size of the experiment is relatively small and careful consideration of the external validity of the results is required, the internal validity of the results is guaranteed, since treatments are randomly assigned to informal workers.

The remainder of this paper proceeds as follows. Section 1 describes the experimental context and design. Section 2 presents the empirical results. The last section discusses the limitations of the study and concludes.

\section{Context and experimental design}

\subsection{Study setting.}

In Iloilo City in the Philippines, a private contractor collects approximately 220 tons of municipal solid waste daily using trucks and hauls it to the Calajunan-controlled disposal facility (Paul et al., 2012). Since there is no household recycling program in Iloilo City, all waste is mixed together.

\footnotetext{
${ }^{2}$ Relatedly, Baksi and Bose (2016) develop a model in which firms in the informal sector endogenously choose their compliance status with an environmental regulation and examine the impact of regulation stringency and enforcement intensity on pollution leakage. Few examples of empirical studies include Cano-Urbina (2015) who studies the role of informal sector jobs in the early stages of a worker's career by using employment survey data in Mexico.
}

Because of these conditions, which are common in many developing countries, including the Philippines, informal workers gather at dumpsites to collect recyclable waste and sell it to nearby junk shops.

As the random sampling of informal workers is difficult, the true population of the waste pickers working at this dumpsite is unknown. In 2010, the German International Cooperation (GIZ) estimated that there were approximately 300 waste picking households. This estimate suggests that the size of the informal sector at this dumpsite is not very large, making it plausible to conduct a census. In this regard, Iloilo is an ideal research site.

The preliminary survey identified several features associated with the job of a waste picker in Iloilo City. First, waste pickers are not employed (see also Birkbeck, 1978), and they act individually ${ }^{3}$. Second, the self-employment nature of this job suggests that waste pickers work whenever they want, and they can even bring their children to their workplace. Third, in general, they earn cash directly from the junk shops. In some cases, they even borrow money from junk shops, which can be interpreted as a patron-client relationship (Gill, 2007). Fourth, workers can obtain payment daily. Fifth, the earnings of each worker are determined by his or her output, which depends on the quantity and quality of sellable waste collected. This is akin to a piece rate scheme. Sixth, roughly half of workers had another job or business before they ventured into waste picking and more than 30 percent of those were farmers or fishers. Finally, the working conditions of waste pickers are low; they have to work outside on a hill of waste, where the smell is bad and flies are crawling elsewhere. Furthermore, in tropical countries such as the Philippines, the high temperature and intense heat of the sun take their toll on the health of workers.

In 2006, the local government of Iloilo City started several programs to support the livelihoods of waste pickers. These programs are assisted by the GIZ, Central Philippine University (CPU), and a nongovernmental organization, Love Our Own Brethren. Their objectives are to support workers at the dumpsite and help them find an alternative source of livelihood (Paul et al., 2012). One alternative jobs that the project has started to provide is the production of solid fuels made from wastepaper (i.e., paper briquettes). (Romallosa \&

\footnotetext{
${ }^{3}$ Some studies report groups of waste pickers within one dumpsite that are fighting for spheres of influence (e.g., Sasaki \& Araki, 2013).
} 
Kraft, 2017). The wastepaper generated at CPU along with procured sawdust and carbonized rice husks are used as inputs for this fuel source. This product can be used as fuel for cooking and can serve as a substitute for charcoal and wood. In 2013, CPU decided to recruit new workers to engage in paper briquette production for three weeks. A randomized experiment was conducted at this time to examine whether changing the payment scheme from the baseline offer would increase the number of waste pickers who accepted the offer.

In addition to providing alternative livelihoods, the city government and GIZ developed an association of

dumpsite waste pickers with optional membership. This association works as a workers' union, providing social security and personal identification, as well as buying recyclable waste to sell together. Almost 33 percent of those interviewed sell their recyclable waste to this association. The executives of the waste pickers' association supported the authors during their experiment. Furthermore, the association's center was used for the paper briquette production. This center is located approximately $100 \mathrm{~m}$ from the main gate of the dumpsite, and therefore the commuting cost for waste pickers who decide to pursue this job is negligible.

\subsection{Treatments.}

Table 1. Payment schemes of the four groups

\begin{tabular}{|c|c|c|c|c|}
\hline Group & 1 & 2 & 3 & 4 \\
\hline Objective 1 & PR-Daily & \multirow{3}{*}{ PR-Three } & & \\
\hline Objective 2 & & & FW-Three & \\
\hline Objective 3 & & & & PR-draw-Three \\
\hline Compensation system & \multicolumn{2}{|c|}{ Piece rate pay } & Fixed wages & Piece rate pay with a draw \\
\hline $\begin{array}{l}\text { Frequency } \\
\text { of payment }\end{array}$ & Daily & & ce every three & \\
\hline
\end{tabular}

Notes: The piece rate pay scheme provides 1 PHP per four pieces of production. The fixed wages scheme provides 65 PHP per day. The piece rate pay with a draw scheme provides a draw of 30 PHP per day and 1 PHP per four pieces of additional production greater than 150 pieces.

Four types of wage payment schemes for paper briquette production are prepared. Table 1 summarizes the four groups of offer letters. Piece rate schemes with daily payments is our first offer $(P R$-Daily). In paper briquette production, employers can easily count the pieces produced by one worker per day, or even an hourly rate. According to the theory of optimal compensation (Lazear, 1995, 1998), if the measurement of outputs is costless and the production cost (e.g., expenditure for materials) is variable, the piece rate equal to the price of the output minus the marginal cost of materials will achieve an efficient level of effort by a worker and minimize moral hazard. Based on this theory, a piece rate scheme, namely 1 Philippine Peso (PHP) per production of four pieces of paper briquettes, is considered ${ }^{4}$. Following

\footnotetext{
${ }^{4}$ The piece rate is calculated as below. First, 40 pieces (approximately 1 kilogram) of paper briquettes can be sold for 11 PHP to retail shops. Second, to produce 40 pieces, less than 1 PHP of carbonized rice husk and sawdust are needed as materials. Thus, 10 PHP (11 minus 1) per 40 pieces is the efficient level of the piece rate. The exchange rate on November 27, 2013 was 1 USD $=43.74$ PHP.
}

evidence of demand for commitment devices, it is hypothesized that waste pickers face a self-control problem related to savings and would prefer payment less frequently than every day. The second proposal (PR-Three) thus offers payment once every three days (i.e., twice each week). It is hypothesized that decreasing payment frequency from every day to once every three days increases the number of workers accepting the offer.

The third proposal ( $F W$-Three) offers fixed wages of 65 PHP per day regardless of how many paper briquettes are produced. Based on the technical team's experience of using old equipment, the productivity of workers is expected to be around 300 pieces per day (five to six working hours). This estimation is used to determine the fixed rate. Note that the preliminary survey found that 15 percent of a waste picker's daily earnings is equal to or less than 65 PHP. This third offer also pays once every three days.

Finally, a combination of piece rates and fixed wages is considered. Although the former can provide an 
incentive for workers to provide their maximum effort, an employer cannot raise its profit since the price equals the marginal cost. Following Lazear (1998), a draw is thus added to the second proposal in the fourth proposal (PR-draw-Three). Workers are guaranteed a draw of 30 PHP per day, while no commission is paid until a worker produces more than 150 pieces. Once this threshold is achieved, an additional 1 PHP per four pieces is paid on top of the 30 PHP already earned. This compensation system can produce a profit of 7.5 PHP per worker per day if a worker produces more than 150 pieces. The PR-Daily and PR-Three groups are compared for objective 1 (see Table 1). The $P R$ Three and FW-Three (PR-draw-Three) groups are compared for objectives 2 and 3.

\subsection{Sample selection and implementation.}

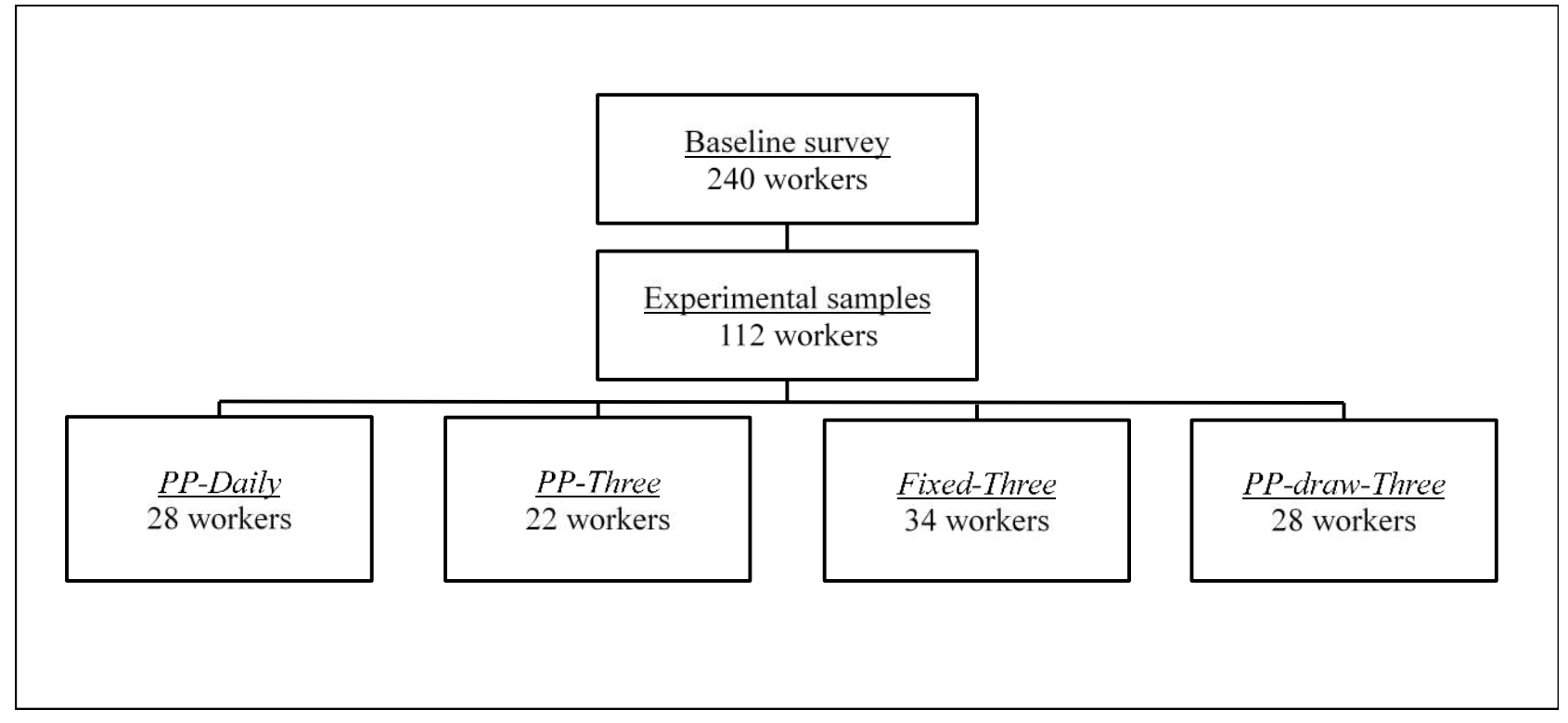

Fig. 1. Experimental design and sample sizes

Figure 1 shows the experimental design and sample size in each stage of the project. In August 2013, the team of researchers attempted to interview all adult (18 years and older) waste pickers working at the dumpsite in Iloilo with the assistance of four enumerators over a 10-day period. As the purpose is to offer an alternative job to adult waste pickers, child waste pickers are excluded from the analysis. In addition, those already involved in existing programs (e.g., handicraft manufacturing) are excluded. The team interviewed 240 adult waste pickers. The team collected workers' characteristics and preferences including their willingness to accept a hypothetical closure of the dumpsite during December 2013. The team asked about the compensation level sufficient to accept a one-month closure of the dumpsite (Willingness to accept closure, PHP). This value measures the stated opportunity cost of being prohibited from collecting waste for one month.

The time-consistent aspects of time preferences are elicited by using survey questions to evaluate the heterogeneity of the impact of less frequent payments. A variable Discount rate is constructed. Higher values imply that they are impatient. Theoretical studies (e.g., Lazear, 1998) consider that risk preferences affect labor supply under fixed wages. Thus, risk preferences are also elicited by using survey questions to evaluate the heterogeneity of the impact of fixed wages. A variable Risk aversion, which is coded from one to eight, is constructed (1-3: risk-seeking individual, 4 or 5: risk-neutral individual, 6-8: risk-averse individual). Hence, higher values imply that an individual is more risk averse.

Envelopes containing the job offer letters were randomly distributed to waste pickers over four days in November 2013. First, the team found and identified a waste picker who was interviewed. Second, four cards were shuffled and shown to the individual face down. Third, the individual picked one card and, finally, the number on the card determined the job offer letter they received. Only one version of the offer letter was given to each waste picker.

The team searched and tried to identify all those interviewed in August. However, identifying them was difficult. Finally, the team identified 112 waste pickers and distributed one envelope to each of them. Admittedly, the experimental subjects were not randomly selected. The association's center was used as the base of operations, and the search for waste pickers by the team always started from that location. The vice president of the waste pickers' association supported the researchers throughout 
this process. This does introduce bias into the sample selection, as it favors waste pickers who often work near the center or who live near the area, suggesting that caution is needed when interpreting the results of the study.

The offer letter constituted two pages. The first page described the job including the starting time, working time, and application process, while the second page set out the substance of the offer. The letters were written in Hiligaynon, the local dialect spoken in Iloilo. The research assistants explained the description of the offer in Hiligaynon if requested.

All workers were asked to join for three weeks from November 27, 2013, except for Sundays. Working hours were set to five hours, from 10 am to $4 \mathrm{pm}$ (excluding a one-hour lunch break). A three-week contract is short for an alternative job. However, paper briquette production by informal workers is in a pilot phase compared with other livelihood programs such as handicraft manufacturing and the production of alternative fuels for cement manufacturing (Paul et al., 2012). Nevertheless, waste pickers expected the acceptance of this offer to lead them toward alternative livelihoods in the long run.
The offer letter mentioned the availability of more than 16 vacancies. An application form was attached to the offer letter. Those who wanted to accept the offer were instructed to fill out the application form, submit it to the association's center, and then attend the orientation scheduled on November 27. Accepting the offer was defined as an individual who attended the orientation. Those who accepted the offer and started producing paper briquettes received a salary from the second day according to their production rate and payment scheme. From November 29, paper briquette production commenced.

Table A1 in the Appendix compares the 112 subjects with those interviewed, but not included in the experiment. Average hourly earnings are higher for the participants of the experiment than nonparticipants. In participant households, an income earner other than the subject is less likely to exist. Both average participants and nonparticipants are risk averse. Importantly, however, nonparticipants are more risk averse than participants. Based on these results, the external validity of the findings is discussed in section 2 .

Table 2 . Summary statistics by group

\begin{tabular}{|c|c|c|c|c|c|c|c|}
\hline & (1) & (2) & (3) & (4) & $(5)$ & (6) & (7) \\
\hline Payment scheme & $\begin{array}{c}P R \\
\text {-Daily }\end{array}$ & $\begin{array}{c}P R \\
\text {-Three }\end{array}$ & $\begin{array}{c}\text { FW } \\
\text {-Three }\end{array}$ & $\begin{array}{l}\text { PR-draw } \\
\text {-Three }\end{array}$ & \multicolumn{3}{|c|}{$\begin{array}{c}\text { Difference } \\
p \text {-value }\end{array}$} \\
\hline Group & 1 & 2 & 3 & 4 & 1 vs 2 & 2 vs 3 & 2 vs 4 \\
\hline \multirow[t]{2}{*}{ Female } & 0.500 & 0.500 & 0.471 & 0.536 & 1.000 & 0.833 & 0.807 \\
\hline & $(0.509)$ & $(0.512)$ & $(0.507)$ & $(0.508)$ & & & \\
\hline \multirow[t]{2}{*}{ Age } & 33.89 & 33.36 & 34.94 & 35.93 & 0.870 & 0.663 & 0.495 \\
\hline & $(10.00)$ & $(12.70)$ & $(13.41)$ & $(13.38)$ & & & \\
\hline \multirow[t]{2}{*}{ Years of education } & 7.393 & 7.114 & 7.147 & 7.321 & 0.727 & 0.965 & 0.770 \\
\hline & $(2.923)$ & $(2.600)$ & $(2.893)$ & $(2.389)$ & & & \\
\hline \multirow[t]{2}{*}{ Average hourly earnings (PHP/hour) } & 20.00 & 22.05 & 16.75 & 22.30 & 0.555 & 0.092 & 0.950 \\
\hline & $(9.013)$ & $(15.22)$ & $(7.831)$ & $(13.48)$ & & & \\
\hline \multirow[t]{2}{*}{ Selling to the association } & 0.393 & 0.227 & 0.382 & 0.357 & 0.221 & 0.232 & 0.330 \\
\hline & $(0.497)$ & $(0.429)$ & $(0.493)$ & $(0.488)$ & & & \\
\hline \multirow[t]{2}{*}{ No other income earner in $\mathrm{HH}$} & 0.214 & 0.136 & 0.206 & 0.214 & 0.487 & 0.516 & 0.487 \\
\hline & $(0.418)$ & $(0.351)$ & $(0.410)$ & $(0.418)$ & & & \\
\hline \multirow[t]{2}{*}{ No other job } & 0.643 & 0.636 & 0.735 & 0.714 & 0.963 & 0.441 & 0.567 \\
\hline & $(0.488)$ & $(0.492)$ & $(0.448)$ & $(0.460)$ & & & \\
\hline \multirow[t]{2}{*}{ Wants to join PB production } & 0.821 & 0.909 & 0.971 & 0.964 & 0.386 & 0.327 & 0.425 \\
\hline & $(0.390)$ & $(0.294)$ & $(0.171)$ & $(0.189)$ & & & \\
\hline \multirow[t]{2}{*}{ Discount rate (1-6) } & 3.214 & 2.500 & 3.000 & 3.286 & 0.219 & 0.360 & 0.186 \\
\hline & $(2.061)$ & $(1.946)$ & $(2.000)$ & $(2.141)$ & & & \\
\hline \multirow[t]{2}{*}{ Risk aversion (1-8) } & 6.964 & 7.318 & 6.735 & 6.179 & 0.576 & 0.270 & 0.093 \\
\hline & $(2.411)$ & $(1.912)$ & $(1.912)$ & $(2.611)$ & & & \\
\hline Willingness to accept closure (PHP) & 5058 & 5568 & 5909 & 5536 & 0.499 & 0.702 & 0.966 \\
\hline
\end{tabular}


Table 2. (cont.) Summary statistics by group

\begin{tabular}{|c|c|c|c|c|c|c|c|}
\hline & $(1)$ & $(2)$ & (3) & $(4)$ & (5) & (6) & $(7)$ \\
\hline Payment scheme & $\begin{array}{c}P R \\
\text {-Daily }\end{array}$ & $\begin{array}{c}P R \\
\text {-Three }\end{array}$ & $\begin{array}{c}\text { FW } \\
\text {-Three }\end{array}$ & $\begin{array}{c}\text { PR-draw } \\
\text {-Three }\end{array}$ & \multicolumn{3}{|c|}{$\begin{array}{c}\text { Difference } \\
p \text {-value }\end{array}$} \\
\hline \multirow{2}{*}{ Group } & 1 & 2 & 3 & 4 & 1 vs 2 & 2 vs 3 & 2 vs 4 \\
\hline & $(2787)$ & $(2331)$ & $(3694)$ & $(2899)$ & & & \\
\hline Observations & 28 & 22 & 34 & 28 & & & \\
\hline Number accepting the offer & 2 & 6 & 4 & 5 & & & \\
\hline Share of those accepting the offer (\%) & 7.1 & 27.3 & 11.8 & 17.9 & & & \\
\hline
\end{tabular}

Notes: Means are reported. Standard deviations are in parentheses. Two observations in group 1 and one observation in group 3 lack data in the Willingness to accept closure category. Discount rate is assessed on a scale from one to six, with higher values meaning the discount rate of an individual is high and the individual is impatient. Risk aversion is assessed on a scale from one to eight, with higher values meaning an individual is highly risk averse. A risk-seeking individual would receive a value between one and three, a risk-neutral individual would receive a value of four or five, and a risk-averse individual would receive a value between six and eight. Willingness to accept closure measures the stated opportunity cost (in PHP) of closing the dumpsite for a month in December 2013.

Table 2 presents the summary statistics of the four groups of the participants of the experiment, as well as the treatment balance for participants. Comparing the variable means across PR-Three and the other three groups using $t$-tests shows that only two variables differ at $p<0.10$. Participants assigned to PR-Three are slightly more productive in the current business than those assigned to FW-Three and slightly more risk averse than those assigned to PR-draw-Three.

\section{Results}

\subsection{Descriptive results}

Table 2 reports the number and percentage of individuals who showed up on the first day. In total, 17 individuals appeared on the first day and they constituted 15.2 percent of the waste pickers who received a job offer. The piece rate with daily payment scheme (PR-Daily) attracted 7.1 percent of recipients, which is the lowest of all. The offer with piece rate pay once every three days (PR-Three) attracted 27.3 percent of those who received a job offer. The offer with fixed wages of 65 PHP per day ( $F W$-Three) attracted 11.8 percent of recipients. Note that according to the survey, 20.6 percent of the recipients of $F W$-Three earn less than 65 PHP by collecting waste. Surprisingly, however, all four applicants from this group earn more than 65 PHP by collecting waste, and two of them earn more than double the fixed rate (150 PHP). The offer of piece rate pay with the draw (PR-draw-Three) attracted 17.9 percent of recipients.

\subsection{Impact of changing payment schemes}

Table 3. Accepting a job offer: marginal effects (logit estimations)

\begin{tabular}{|c|c|c|c|c|c|c|}
\hline \multicolumn{7}{|c|}{ Dependent variable is 1 if the offer is accepted and 0 otherwise. } \\
\hline & $(1)$ & $(2)$ & (3) & (4) & $(5)$ & (6) \\
\hline & & & & Daily payment & Fixed wages & PR with a draw \\
\hline \multirow[t]{2}{*}{ Daily payment } & $-0.189^{*}$ & $-0.164^{* *}$ & $-0.165^{* *}$ & $-0.304^{* *}$ & $-0.321^{*}$ & $-0.366^{*}$ \\
\hline & $(0.0983)$ & $(0.0745)$ & $(0.0805)$ & $(0.150)$ & $(0.180)$ & $(0.196)$ \\
\hline \multirow[t]{2}{*}{ Fixed wages } & -0.123 & $-0.128^{*}$ & -0.105 & -0.213 & $-0.225^{*}$ & -0.257 \\
\hline & $(0.0846)$ & $(0.0685)$ & $(0.0714)$ & $(0.151)$ & $(0.134)$ & $(0.171)$ \\
\hline \multirow[t]{2}{*}{ Piece rate pay with a draw } & -0.0651 & -0.0833 & -0.0809 & -0.142 & -0.150 & -0.172 \\
\hline & $(0.0825)$ & $(0.0628)$ & $(0.0668)$ & $(0.126)$ & $(0.130)$ & $(0.137)$ \\
\hline \multirow[t]{2}{*}{ Discount rate } & & 0.00574 & 0.00472 & & & \\
\hline & & $(0.0138)$ & $(0.0133)$ & & & \\
\hline \multirow[t]{2}{*}{ Risk aversion } & & -0.0129 & $-0.0155^{*}$ & -0.0184 & -0.0195 & -0.0222 \\
\hline & & $(0.0108)$ & $(0.00912)$ & $(0.0179)$ & $(0.0183)$ & $(0.0207)$ \\
\hline \multirow[t]{2}{*}{ Female } & & $0.111^{*}$ & $0.105^{*}$ & $0.190^{* *}$ & $0.201^{* *}$ & $0.229^{* *}$ \\
\hline & & $(0.0578)$ & $(0.0588)$ & $(0.0840)$ & $(0.0962)$ & $(0.106)$ \\
\hline \multirow[t]{2}{*}{ Age } & & 0.000436 & 0.00103 & & & \\
\hline & & $(0.00240)$ & $(0.00231)$ & & & \\
\hline \multirow[t]{2}{*}{ Years of education } & & 0.00252 & 0.00217 & & & \\
\hline & & $(0.00858)$ & $(0.00806)$ & & & \\
\hline \multirow[t]{2}{*}{ Average hourly earnings } & & 0.00144 & 0.00252 & & & \\
\hline & & $(0.00206)$ & $(0.00215)$ & & & \\
\hline
\end{tabular}


Table 3 (cont.) Accepting a job offer: marginal effects (logit estimations)

\begin{tabular}{|c|c|c|c|c|c|c|}
\hline \multicolumn{7}{|c|}{ Dependent variable is 1 if the offer is accepted and 0 otherwise. } \\
\hline & $(1)$ & $(2)$ & (3) & (4) & $(5)$ & $(6)$ \\
\hline & & & & Daily payment & Fixed wages & PR with a draw \\
\hline \multirow[t]{2}{*}{ Selling to the association } & & $0.132^{* *}$ & $0.142^{* \star *}$ & $0.231^{* *}$ & $0.244^{* *}$ & $0.279^{\star * *}$ \\
\hline & & $(0.0529)$ & $(0.0523)$ & $(0.101)$ & $(0.100)$ & $(0.104)$ \\
\hline \multirow[t]{2}{*}{ No other income earner in $\mathrm{HH}$} & & -0.129 & $-0.141^{*}$ & -0.242 & -0.255 & -0.292 \\
\hline & & $(0.0794)$ & $(0.0782)$ & $(0.160)$ & $(0.160)$ & $(0.191)$ \\
\hline \multirow[t]{2}{*}{ No other job } & & -0.0332 & -0.0162 & & & \\
\hline & & $(0.0638)$ & $(0.0573)$ & & & \\
\hline \multirow[t]{2}{*}{ Wants to join PB production } & & 0.0824 & 0.115 & & & \\
\hline & & $(0.0986)$ & $(0.0992)$ & & & \\
\hline \multirow[t]{2}{*}{ Willingness to accept closure } & & & $-1.23 e-05$ & & & \\
\hline & & & $(7.94 \mathrm{e}-06)$ & & & \\
\hline \multicolumn{7}{|c|}{ Settings of variables to calculate ME } \\
\hline Daily payment & Mean & Mean & Mean & Mean & 0 & 0 \\
\hline Fixed wages & Mean & Mean & Mean & 0 & Mean & 0 \\
\hline Piece rate pay with a draw & Mean & Mean & Mean & 0 & 0 & Mean \\
\hline Control variables & - & Mean & Mean & Mean & Mean & Mean \\
\hline Observations & 112 & 112 & 109 & 112 & 112 & 112 \\
\hline Log-likelihood & -45.55 & -36.65 & -34.90 & -37.33 & -37.33 & -37.33 \\
\hline Wald $X$ squared & 3.992 & 24.07 & 29.49 & 21.05 & 21.05 & 21.05 \\
\hline Pseudo R squared & 0.0449 & 0.231 & 0.260 & 0.217 & 0.217 & 0.217 \\
\hline
\end{tabular}

Notes: Marginal effects are reported. Robust standard errors are in parentheses. *** Indicates statistical significance at the $1 \%$ level. ** Indicates statistical significance at the 5\% level. * Indicates statistical significance at the $10 \%$ level. Constant terms are not reported.

To estimate the average treatment effects of changing payment schemes, regression analyses are conducted. The outcome variable of interest is the acceptance of the job offer (A) by waste pickers. Let $A_{i}$ be an indicator variable for accepting the job offer by individual $i . P R-$ Three is considered to be the reference group. Let Daily be an indicator variable for receiving an offer letter for $P R$-Daily, Fixed be an indicator variable for receiving an offer letter for $F W$-Three, and Draw be an indicator variable for receiving an offer letter for $P R$-draw-Three. Let $A^{*}$ be an unobserved or latent variable. Suppose that:

$$
A_{i}^{*}=\beta_{1} \text { Daily }_{i}+\beta_{2} \text { Fixed }_{i}+\beta_{3} \text { Draw }_{i}+\gamma^{\prime} X_{i}+\varepsilon_{i},
$$

where $X_{i}$ is a vector of the demographic and other by maximum likelihood estimation in a logit model. survey responses and $\varepsilon_{i}$ is the error term for individual. The coefficients $\beta$ and $\gamma$ are estimated $\quad=1$ is given by

$$
\operatorname{Pr}\left(A_{i}=1\right)=\frac{\exp \left(\beta_{1} \text { Daily }_{i}+\beta_{2} \text { Fixed }_{i}+\beta_{3} \text { Draw }_{i}+\gamma^{\prime} X_{i}\right)}{1+\exp \left(\beta_{1} \text { Daily }_{1}+\beta_{2} \text { Fixed }_{i}+\beta_{3} \text { Draw }_{i}+\gamma^{\prime} X_{i}\right)} .
$$

Table 3 shows the estimation results of equation (2). In columns 1-3, the marginal effects are calculated by setting all the independent variables to the mean values. The results show a significant and robust negative effect of daily payment, meaning that changing payment frequency from daily payment to once every three days increases the probability of accepting the job offer. The effect of changing from piece rates to fixed wages of 65 PHP per day is negative, although the result is not robust. The effect of adding a draw of 30
PHP until 150 briquettes are produced is not statistically significant.

To precisely estimate the magnitude of the effect of changing from PR-Three to the other three payment schemes, the marginal effects are calculated with the model that includes the four demographic variables that are significant in column 3, setting those to their mean values; the payment scheme variables not of interest are set to zero. Columns $4-6$ of Table 3 show the results, 
highlighting that changing from $P R$-Three to $P R$ Daily decreases the probability of accepting the job offer by 30.4 percentage points (column 4). Further, changing from PR-Three to FW-Three decreases the probability of accepting the job offer by 22.5 percentage points (column 5). There is no significant effect of changing from $P R$ Three to PR-draw-Three (column 6).

Table 3 shows the correlations between several of the sociodemographic variables and the acceptance of the job offer. The transactional relationship with the waste pickers' association (Selling to the association) has a positive and

highly significant effect on accepting the job offer. Women are more likely than men to change their jobs. The negative sign for the No other income earner in the household $(\mathrm{HH})$ variable suggests that waste pickers who are the only income earners within a family are less likely to leave the dumpsite and work in a new job. Riskaverse waste pickers are less likely to accept a new job offer, although the result is not robust. The stated preference to accept a job offer during the interview survey does not explain their actual behavior (Wants to join PB production).

\subsection{Heterogeneous treatment effects}

Table 4. Accepting a job offer with interaction terms: coefficients (logit estimations)

\begin{tabular}{|c|c|c|}
\hline \multicolumn{3}{|c|}{ Dependent variable is 1 if the offer is accepted and 0 otherwise. } \\
\hline & (1) & (2) \\
\hline \multirow[t]{2}{*}{ Daily payment } & $-6.473^{\star \star *}$ & $-9.484^{* \star *}$ \\
\hline & $(2.256)$ & $(2.440)$ \\
\hline \multirow[t]{2}{*}{ Daily payment * Discount rate } & $1.036^{* *}$ & $1.603^{* * *}$ \\
\hline & $(0.417)$ & $(0.517)$ \\
\hline \multirow[t]{2}{*}{ Fixed wages } & $-4.288^{*}$ & $-10.54^{* \star *}$ \\
\hline & $(2.541)$ & $(2.751)$ \\
\hline \multirow[t]{2}{*}{ Fixed wages * Risk aversion } & 0.448 & $1.242^{* \star *}$ \\
\hline & $(0.367)$ & $(0.385)$ \\
\hline \multirow[t]{2}{*}{ Piece rate pay with a draw } & $-3.695^{* *}$ & $-6.796^{* \star *}$ \\
\hline & $(1.729)$ & $(2.223)$ \\
\hline \multirow[t]{2}{*}{ Piece rate pay with a draw * Risk aversion } & $0.431^{*}$ & $0.743^{* *}$ \\
\hline & $(0.253)$ & $(0.335)$ \\
\hline \multirow[t]{2}{*}{ Discount rate } & 0.0535 & -0.148 \\
\hline & $(0.138)$ & $(0.190)$ \\
\hline \multirow[t]{2}{*}{ Risk aversion } & $-0.431^{* *}$ & $-0.985^{\star \star \star}$ \\
\hline & $(0.176)$ & $(0.256)$ \\
\hline \multirow[t]{2}{*}{ Female } & & $2.397^{* *}$ \\
\hline & & $(0.991)$ \\
\hline \multirow[t]{2}{*}{ Age } & & -0.00748 \\
\hline & & $(0.0312)$ \\
\hline \multirow[t]{2}{*}{ Years of education } & & 0.0673 \\
\hline & & $(0.111)$ \\
\hline \multirow[t]{2}{*}{ Average hourly earnings } & & 0.0404 \\
\hline & & $(0.0272)$ \\
\hline \multirow[t]{2}{*}{ Selling to the association } & & $2.499^{\star * \star}$ \\
\hline & & $(0.806)$ \\
\hline \multirow[t]{2}{*}{ No other income earners in the $\mathrm{HH}$} & & -1.536 \\
\hline & & $(1.169)$ \\
\hline \multirow[t]{2}{*}{ No other job } & & -0.268 \\
\hline & & $(0.999)$ \\
\hline \multirow[t]{2}{*}{ Wants to join PB production } & & $2.783^{* *}$ \\
\hline & & $(1.268)$ \\
\hline Observations & 112 & 112 \\
\hline Log-likelihood & -42.15 & -31.71 \\
\hline Wald $x$ squared & 13.98 & 31.96 \\
\hline Pseudo R squared & 0.116 & 0.335 \\
\hline
\end{tabular}

Notes: Coefficients are reported. Robust standard errors are in parentheses. *** Indicates statistically significant at the $1 \%$ level.

** Indicates statistically significant at the 5\% level. * Indicates statistically significant at the $10 \%$ level. Constant terms are not reported. 
To examine the heterogeneity of the treatment effects by preferences, interactions with the offer letter dummy variables and variables of time and risk preferences are added into equation (1). Table 4 reports the positive coefficient of the estimation of the interaction term of PR-Daily and the discount rate. Note that there is no significant correlation between a high discount rate and the acceptance of the job offer (see Table 3). This finding implies that, on average, changing payment frequency from once every three days to daily decreases the probability that an individual will accept the job offer. However, the magnitude of this decrease in probability is lower if an individual has a high discount rate.

Column 2 in Table 4 reports that the coefficient of the interaction between the dummy variable of $F W$-Three and risk aversion is positive and significant. Note the slightly negative correlation of risk aversion and the acceptance of the job offer (see Table 3). Thus, risk-averse individuals are less likely to accept the job offer; however, the possibility that decreases with risk aversion falls if we change from piece rates to fixed wages. Similarly, the interaction of the dummy variable of $P R$-draw-Three and risk aversion is positive and significant. This finding implies that risk-averse individuals are less likely to accept the job offer with piece rate pay once every three days. However, the possibility that decreases with risk aversion falls if we add a draw, meaning that a draw of 30 PHP per day encourages risk-averse individuals to accept the offer.

Another interpretation of these results is possible. The impact of changing from piece rates to fixed wages of 65 PHP from the previous analysis is negative. Hence, the positive coefficient of the interaction of $F W$-Three and risk aversion suggests that the negative effect of 65 PHP per day reduces if an individual is more risk averse.

\section{Conclusion}

Environmental policies often force job changes for workers in various industries, and this can be considered to be a social cost. Considering the negative impact of such policy interventions, including the job losses caused by the closure of an open dumpsite, those who operate waste management services face an increasing normative expectation to handle the issues

\footnotetext{
${ }^{5}$ While less frequent payment may be demanded by individuals with a self-control problem related to savings, such people may also face a self-control problem at work, which Kaur et al. (2015) find. They argue that a self-control problem at work may be mitigated by more frequent payment.
}

responsibly by providing alternative employment opportunities for waste pickers. This study involved a field experiment at a dumpsite in the Philippines to examine the effect of changing payment schemes on the number of waste pickers accepting the new job offer.

The data of ex-post interviews suggest an interpretation of the main finding that a change in payment frequency from once every three days to daily decreases the probability of accepting the job offer by about 30 percentage points. Four days after production started, two workers in the daily payment group asked us to change their payment frequency so that their salary would be paid two weeks later, claiming they wanted to generate greater savings. This anecdotal evidence suggests that the estimation results reveal evidence of waste pickers' self-control problem related to savings. In this sense, a new job with less frequent payment can serve as a commitment device. While alternative interpretations are possible, for example, daily payments are often associated with precarious jobs and this may lead to less acceptance, it is believed they are less likely, since the participants recognized that public sector organizations were offering these new jobs and that they had already implemented similar programs. That said, the findings do not imply that less frequent payments are generally better ${ }^{5}$. The authors believe this to be the case because the less frequent offer involved payment once every three days, which is more frequent than the common payment practice of once per month. Further studies are, however, needed to examine the preferred payment frequency for waste pickers as well as other low-income individuals in developing countries.

We found that waste pickers offered fixed wages of 65 PHP per day are less likely to accept a new job compared with those offered the piece-rate pay option. There are two potential explanations for this decision: (i) they simply prefer an uncertain offer, and (ii) they can successfully estimate their own productivity. In the production undertaken immediately after this field experiment, workers who received the second proposal (PR-Three) earned more than $65 \mathrm{PHP}$ on average, suggesting that expected productivity in the production of paper briquettes is higher than 65 PHP, possibly because of the installation of new equipment. To mitigate inequality between the other groups, the fixed rate of pay for $F W$ Three was increased to 100 PHP from the first day. Nonetheless, average production by workers under the piece rate scheme was still twice as 
large as the group with fixed wages. This observation is consistent with existing studies (e.g., Shearer, 2004), implying that the piece rate scheme can decrease moral hazard and raise labor supply after a job change.

The fact that the transactional relationship with the waste pickers' association has a positive and highly significant effect on accepting the job offer makes sense, as the association supported the recruiting and provided the authors with a workplace for the alternative job. Indeed, evidence of a strong bond between waste pickers and buyers has also been demonstrated in previous studies (Hayami et al., 2006; Gill, 2007), suggesting that social networks such as buyerseller relationships affect the decision to change one's job.

Two concerns about the external validity of the authors findings should be mentioned here. First, there is concern about sample selection bias. Among the 240 workers surveyed before the intervention, only 112 participated in the experiment. Note that participants are less risk averse compared with nonparticipants (see Table A1 in the Appendix) and that the negative effect of changing from piece rates to fixed wages lowers with risk aversion (see Table 4). These results imply that the positive effect of piece rate pay may be overestimated. Second, there is concern about the specific sample problem (Peters et al., 2016). Since various programs have been conducted at the dumpsite in Iloilo City (Paul et al., 2012; Romallosa \& Kraft, 2017), the participants are more familiar with these kinds of job offers, distinguishing them from the waste pickers at other dumpsites to some extent. However, although the participants recognized that they were in some kind of project driven by the local government, they might not have understood the intentions of the treatments. Thus, the authors believe that the potential hazards (related to the awareness of the study) to both the treatment group (the Hawthorne effect) and the control group (the John Henry effect) are less likely. Indeed, the impacts of changing payment scheme in the formal sector on job changes in the informal sector do not generate a general equilibrium effect. Thus, the proposed treatments can be scaled up despite external validity concerns.

Finally, it is more difficult to encourage men to change their jobs compared with women, especially when they are the only income earners in a household and show risk aversion. Note that this study considers the job change behavior of waste pickers to be a decision made by the individual alone. This assumption might need to be modified, as the decision to change one's job also concerns the entire household. Further studies are thus required to explore how to encourage those who did not accept the job offer in this study.

\section{Acknowledgements}

The authors thank Salome P. Villamor, Neil Ravena, Josephine T. Alcantara, Maribelle R. Pisueña, Suzette Pisueña, and Maria Glenn Clomer at the GSO of Iloilo City for collaborating on the field work, Lorelie T. Secatin, Yukie Kobayashi at NGO LOOB, Klaus Hanuschke and Johannes G. Paul at the GIZ for cooperation throughout this project, Francis G. Capino, Kristofer John C. Hornada, Lucio E. Laraño and Kyo Tamura for excellent research and field assistance; Akira Hibiki, Yuki Higuchi, Shinsuke Ikeda, Keisuke Kawata, Maiko Sakamoto, Yasuyuki Sawada, Aya Suzuki, Kenji Takeuchi, Yasuyuki Todo and David YanagizawaDrott for helpful comments. The paper has benefited from comments by seminar participants at Kobe, Hiroshima, National Institute for Environmental Studies, Tokyo, Osaka and Kochi University of Technology, and conference participants at the 5th World Congress of Environmental and Resource Economists, SEEPS 2014, Hayami Conference 2014 and JEA 2015 Autumn meeting. This work was supported by Grant for Environmental Research Projects from the Sumitomo Foundation and JSPS Grant-in-Aid for Scientific Research on Innovative Areas 25101003.

\section{References}

1. Agunwamba, J. C. (2003). Analysis of scavengers? Activities and recycling in some cities of Nigeria. Environmental Management, 32, 116-127.

2. Albrecht, J., Navarro, L., \& Vroman, S. (2009). The effects of labour market policies in an economy with an informal sector. Economic Journal 119, 1105-1129.

3. Ashraf, N., Karlan, D., \& Yin, W. (2006). Tying Odysseus to the mast: Evidence from a commitment savings product in the Philippines. Quarterly Journal of Economics, 121, 635-672.

4. Asim, M., Batool, S. A., \& Chaudhry, M. N. (2012). Scavengers and their role in the recycling of waste in Southwestern Lahore. Resources, Conservation and Recycling, 58, 152-162.

5. Baksi, S., \& Bose, P. (2016). Informal sector, regulatory compliance, and leakage. Journal of Development Economics, 121, 166-176. 
6. Birkbeck, C. (1978). Self-employed proletarians in an informal factory: the case of Cali's garbage dump. World Development, 6, 1173-1185.

7. Biswas, A. K., Farzanegan, M. R., \& Thum, M., (2012). Pollution, shadow economy and corruption: theory and evidence. Ecological Economics, 75, 114-125.

8. Blackman, A., \& Bannister, G. J. (1998). Community pressure and clean technology in the informal sector: an econometric analysis of the adoption of propane by traditional Mexican brickmakers. Journal of Environmental Economics and Management, 35, 1-21.

9. Blackman, A., Shih, J.-S., Evans, D., Batz, M., Newbold, S., \& Cook, J. (2006). The benefits and costs of informal sector pollution control: Mexican brick kilns. Environment and Development Economics, 11, 603-627.

10. Bovenberg, A. L., \& van der Ploeg, F. (1994). Environmental policy, public finance and the labour market in a second-best world. Journal of Public Economics, 55, 349-390.

11. Bryan, G., Karlan D., \& Nelson, S. (2010). Commitment devices. Annual Review of Economics, 2, 671-698.

12. Cano-Urbina, J. (2015). The role of the informal sector in the early careers of less-educated workers. Journal of Development Economics, 112, 33-55.

13. Chaudhuri, S., \& Mukhopadhyay, U. (2006). Pollution and informal sector: a theoretical analysis. Journal of Economic Integration, 21, 363-378.

14. Fugazza, M., \& Jacques, J.-F. (2004). Labor market institutions, taxation and the underground economy. Journal of Public Economics, 88, 395-418.

15. Gill, K. (2007). Interlinked contracts and social power: patronage and exploitation in India's waste recovery market. Journal of Development Studies, 43, 1448-1474.

16. Greenstone, M. (2002). The impacts of environmental regulations on industrial activity: evidence from the 1970 and 1977 Clean Air Act Amendments and the Census of Manufactures. Journal of Political Economy, 110, 11751219.

17. Gutberlet, J., \& Baeder, A. M. (2008). Informal recycling and occupational health in Santo Andre, Brazil. International Journal of Environmental Health Research, 18, 1-15.

18. Hayami, Y., Dikshit, A. K., \& Mishra, S. N. (2006). Waste pickers and collectors in Delhi: poverty and environment in an urban informal sector. Journal of Development Studies, 42, 41-69.

19. Kaur, S., Kremer, M., \& Mullainathan S. (2015). Self-control at work. Journal of Political Economy, 123, $1227-$ 1277.

20. Lazear, E. P. (1995). Personnel Economics. Boston: Massachusetts Institute of Technology.

21. Lazear, E. P. (1998). Personnel Economics for Managers. New York: Wiley.

22. Liu, M., Shadbegian, R., \& Zhang, B. (2017). Does environmental regulation affect labor demand in China? Evidence from the textile printing and dyeing industry. Journal of Environmental Economics and Management, 86, 277-294.

23. Medina, M. (1998). Border scavenging: a case study of aluminum recycling in Laredo, TX and Nuevo Laredo, Mexico. Resources Conservation and Recycling, 23, 107-126.

24. Medina, M. (2000). Scavenger cooperatives in Asia and Latin America. Resources Conservation and Recycling, 31, 51-69.

25. Moreno-Sanchez, R. D. P. \& Maldonado J. H. (2006). Surviving from garbage: the role of informal waste-pickers in a dynamic model of solid-waste management in developing countries. Environment and Development Economics, 11, 371-391.

26. Nzeadibe, T. C. (2009). Solid waste reforms and informal recycling in Enugu Urban Area, Nigeria. Habitat International, 33, 93-99.

27. Parizeau, K. (2015). When assets are vulnerabilities: an assessment of informal recyclers livelihood strategies in Buenos Aires, Argentina. World Development, 67, 161-173.

28. Paul, J. G., Arce-Jaque, J., Ravena, N., \& Villamor, S. P. (2012). Integration of the informal sector into municipal solid waste management in the Philippines: what does it need? Waste Management, 32, 2018-2028.

29. Peters, J., Langbein, J., \& Roberts, G. (2016). Policy evaluation, randomized controlled trials, and external validity: a systematic review. Economics Letters, 147, 51-54.

30. Prendergast, C. (1999). The provision of incentives in firms. Journal of Economic Literature, 37, 7-63.

31. Romallosa, A., \& Kraft, E. (2017). Feasibility of biomass briquette production from municipal waste streams by integrating the informal sector in the Philippines. Resources, 6, 12.

32. Sasaki, S., \& Araki, T. (2013). Employer-employee and buyer-seller relationships among waste pickers at final disposal site in informal recycling: the case of Bantar Gebang in Indonesia. Habitat International, 40, 51-57.

33. Shearer, B. (2004). Piece rates, fixed wages and incentives: evidence from a field experiment. Review of Economic Studies, 71, 513-534.

34. Tirado-Soto, M. M., \& Zamberlan F. L. (2013). Networks of recyclable material waste-picker's cooperatives: an alternative for the solid waste management in the city of Rio de Janeiro. Waste Management, 33, 1004-1012.

35. Walker, W. R. (2011). Environmental regulation and labor reallocation: evidence from the Clean Air Act. American Economic Review, 101, 442-447.

36. Walker, W. R. (2013). The transitional costs of sectoral reallocation: evidence from the Clean Air Act and the workforce. Quarterly Journal of Economics, 128, 1787-1835. 
Environmental Economics, Volume 9, Issue 2, 2018

37. Wilson, D. C., Araba, A. O., Chinwah, K., \& Cheeseman C. R. (2009). Building recycling rates through the informal sector. Waste Management, 29, 629-635.

38. Zaied, Y. B., Cheikh, N. B., Nguyen P., \& Mahjoub, M. B. (2018). Waste management policy and employment: the case of France. Environmental Economics, 9, 38-46. 


\section{Appendix}

Table A1. Workers' characteristics by participation status

\begin{tabular}{|c|c|c|c|}
\hline & Nonparticipants & Participants & $\begin{array}{c}\text { Difference } \\
p \text {-value }\end{array}$ \\
\hline & (1) & (2) & (3) \\
\hline \multirow[t]{2}{*}{ Female } & 0.539 & 0.500 & 0.548 \\
\hline & $(0.500)$ & $(0.502)$ & \\
\hline \multirow[t]{2}{*}{ Age } & 35.070 & 34.616 & 0.785 \\
\hline & (13.323) & (12.360) & \\
\hline \multirow[t]{2}{*}{ Years of education } & 6.793 & 7.246 & 0.216 \\
\hline & $(2.931)$ & $(2.692)$ & \\
\hline \multirow[t]{2}{*}{ Average hourly earnings } & 17.452 & 19.992 & 0.052 \\
\hline & $(8.571)$ & $(11.462)$ & \\
\hline \multirow[t]{2}{*}{ Selling to the association } & 0.313 & 0.348 & 0.559 \\
\hline & $(0.465)$ & $(0.479)$ & \\
\hline \multirow[t]{2}{*}{ No other income earner in $\mathrm{HH}$} & 0.328 & 0.196 & 0.021 \\
\hline & $(0.471)$ & $(0.399)$ & \\
\hline \multirow[t]{2}{*}{ No other job } & 0.602 & 0.688 & 0.167 \\
\hline & $(0.492)$ & $(0.466)$ & \\
\hline \multirow[t]{2}{*}{ Wants to join PB production } & 0.883 & 0.920 & 0.345 \\
\hline & $(0.323)$ & $(0.273)$ & \\
\hline \multirow[t]{2}{*}{ Discount rate } & 2.773 & 3.027 & 0.329 \\
\hline & $(1.977)$ & $(2.033)$ & \\
\hline \multirow[t]{2}{*}{ Risk aversion } & 7.305 & 6.768 & 0.034 \\
\hline & $(1.653)$ & $(2.238)$ & \\
\hline \multirow[t]{2}{*}{ Willingness to accept closure } & 5218.254 & 5541.284 & 0.429 \\
\hline & $(3207.177)$ & $(3016.259)$ & \\
\hline Observations & 128 & 112 & \\
\hline
\end{tabular}

Notes: Means are reported from the survey data for participants and nonparticipants. Standard deviations are in parentheses. See the notes of Table 2 for a description of the variables. One observation from nonparticipants lacks data on average hourly earnings. Two observations from nonparticipants and three observations from participants lack data on the willingness to accept closure category. 